\title{
Native American lithic procurement along the international border in the boot heel region of southwestern New Mexico
}

\author{
K. E. Zeigler ${ }^{1}$, P. Hogan ${ }^{2}$, C. Hughes ${ }^{2}$, and A. Kurota ${ }^{2}$ \\ ${ }^{1}$ Zeigler Geologic Consulting, 14500 Oakwood Place NE, Albuquerque, NM, USA \\ ${ }^{2}$ Office of Contract Archeology, MSC 07 4230, University of New Mexico, Albuquerque, NM, 87131, USA
}

Received: 5 November 2010 - Published in Solid Earth Discuss.: 1 December 2010

Revised: 15 April 2011 - Accepted: 3 May 2011 - Published: 14 June 2011

\begin{abstract}
Multidisciplinary field projects can be very useful to a more fundamental understanding of the world around us, though these projects are not as common as they should be. In particular, the combination of archeology and geology combines our understanding of human behavior and human use of the landscape with an intimate knowledge of geologic processes and the materials available for human use in order to gain a broader understanding of human-Earth interaction. Here we present data from a cross-disciplinary project that uses a common dataset, archeological artifacts, to explore the anthropological and geologic implications of useage patterns. Archeological excavations and surveys conducted by the Office of Contract Archeology in 2007 along the route of the proposed international border fence reveal patterns of use of geologic materials by Archaic, Formative and Protohistoric Native Americans in the Boot Heel of southwestern New Mexico. Thousands of artifacts were recorded in multiple sites from Guadalupe Pass in the southern Peloncillo Mountains to the Carrizalillo Hills west of Columbus. We identified the lithologies of artifacts, ranging from projectile points to groundstones, and then constructed material movement maps based on either known procurement sites ("quarries") or outcrops identified as the closest source to a given site for each lithology. Not unexpectedly, the majority of the rock types utilized by native peoples are local siliceous volcanic materials. However, several artifacts constructed from obsidian were transported into the region from northern Mexico and eastern Arizona, indicating long-distance travel and/or trade routes. We also examine useage pattern difference between Archaic, Formative and Protohistoric sites.
\end{abstract}

\section{Correspondence to: K. E. Zeigler} (zeiglergeo@gmail.com)
Additionally, a dramatic change in distribution of sources for geologic materials occurs between one pre-Spanish site and one post-Spanish site that are adjacent to one another.

\section{Introduction}

Lithic procurement strategy in the Boot Heel region of southwestern New Mexico has largely gone untreated in the archaeological literature. This is primarily because there has been relatively little archaeology done in this area in recent years, but is also due to a lack of documentation of the lithic raw material sources in the area. Here we provide a description of the lithic resources in and around the Boot Heel and use this information to examine patterns of lithic procurement among the Archaic, Formative and Protohistoric periods of the area. Data were collected from sites recently recorded by the Office of Contract Archeology (OCA) for the proposed tactical barrier fence to be constructed on the USMexico international border by the Department of Homeland Security. Lithic material types that were utilized at these sites are identified and described in detail and possible source localities for these materials are identified. The relative proportions that these sources were utilized on the sites assigned to the temporal periods in question are then analyzed to determine similarities and differences among them.

The artifacts under analysis in this chapter were compiled from three separate project areas related to the border fence project. These projects ranged from the Dog Mountains in the southeastern Boot Heel to the Carrizalillo Hills in the East and included the eastern border of the Boot Heel (Figs. 1, 2). The broad project areas are referred to in this chapter, from west to east, as HV 5-8, Three Sites and Nineteen Canyon.

Published by Copernicus Publications on behalf of the European Geosciences Union. 

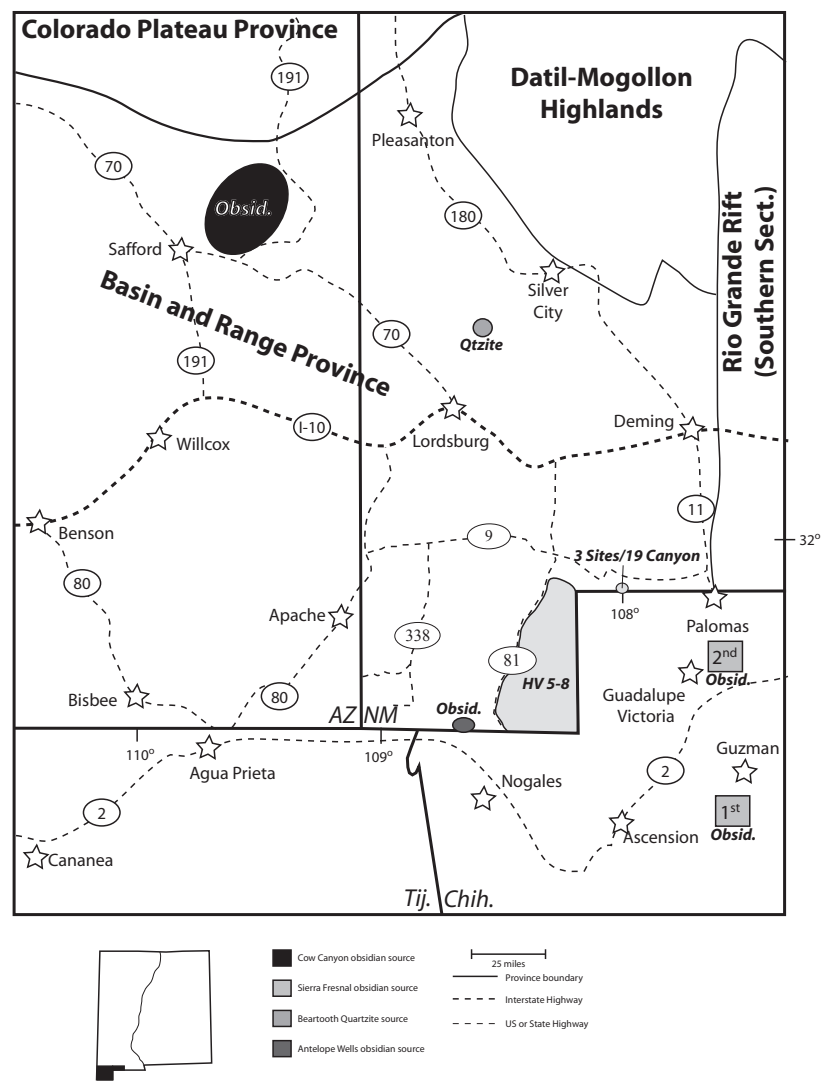

Fig. 1. Location of the study area in regional context. Known locations for distinct geologic materials are indicated by shaded areas.

Nearly all of the lithic materials on the sites were likely procured from the major geologic features of the region. The Boot Heel of New Mexico, as well as southeastern Arizona and northern Mexico are part of the Basin and Range Province of western North America, which is characterized by extensional faulting, producing uplifted blocks of Paleozoic and Mesozoic strata and intervening basins with predominantly Quaternary sediments. In addition, the San Juan volcanic field extends along the Arizona-New Mexico border from northern Mexico into southwestern Colorado and is comprised of Tertiary-aged silicic igneous flows and domes.

This exploration of human behavior was necessarily limited given the preliminary nature of the data set. Our first objective was to assess the availability and quality of lithic raw materials in the Boot Heel area to provide baseline data for this and future studies of lithic procurement activities and mobility strategies. Second, the Average Minimum Distance (AMD) statistic was formulated by $\mathrm{CH}$ to assess the relative mobility of resident groups during the Archaic, Formative, and Protohistoric time periods. The relative mobility of Formative groups was of particular interest as some groups in southern New Mexico were sedentary agriculturalists, while others continued to derive a significant proportion of their diet from hunting and gathering. A third objective was to

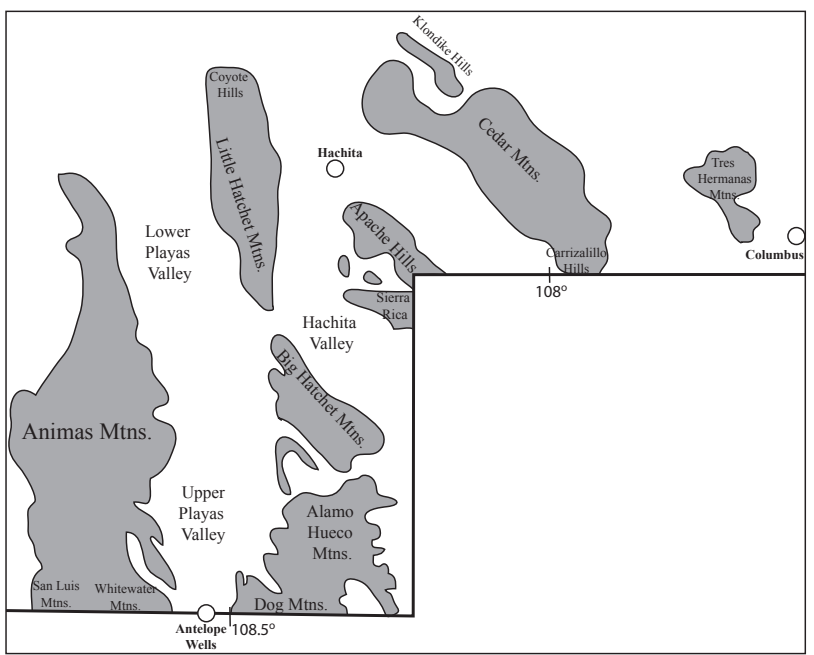

Fig. 2. Physiographic map of southwestern New Mexico.

use raw material proportions for the individual site clusters to begin tracking the movements of groups during the different time periods. This last objective was not fully achieved, in large part because it appears that the groups were predominantly using the local sources of tool stone and carrying little with them as they moved from one site cluster to another. These results are consistent with other observations suggesting that lithic procurement strategies will vary depending on the availability of lithic raw materials (e.g., Andrefsky, 1994) but the behavior could not have been anticipated until we had mapped potential lithic sources in the study area.

\section{Methods}

\subsection{Material recording}

The artifacts and raw materials used here were recorded by several individuals in two different settings. All of HV 58 were recorded in the field during pedestrian survey. Approximately 10 recorders (including $\mathrm{CH}$ ) made designations of material type for lithic artifacts based on their accumulated knowledge, a common practice during cultural resource survey. The remaining artifacts were recovered during the data recovery phase and were recorded in the OCA laboratory. Artifacts were washed with water and toothbrushes upon their return to lab. Material recording was then conducted by three individuals with some level of lithic analysis training (including $\mathrm{CH}$ ), occasionally with the aid of a lowpowered microscope.

A representative sample of specimens was selected and examined by a professional geologist (KZ) and described in detail. These included recovered artifacts and source samples that were analyzed in-hand and specimens in high-resolution photographs from survey. Munsell colors for recovered 
specimens are from the 1991 Geological Society of America Rock-Color Chart. Items that are tentatively identified from high resolution photographs are described only by basic lithotype and Munsell colors for these specimens are estimated as a range of color possibilities. Inferences made from these examinations were selectively applied to the recorded artifact data mentioned in the previous two paragraphs in order to fix observed errors in the database.

The geologic base map for the Boot Heel region was constructed by scanning in geologic maps of Arizona (Reynolds, 1988), New Mexico (Wilks, 2005) and northern Mexico and redrafting the units into a consistent map. High resolution geologic maps (1:24,000 scale) were used to modify the base map where needed (Zeller, 1959, 1962, 1966, 1970; Soule, 1972; Seager and Clemmons, 1988). Many units have been simplified, especially for sedimentary packages that include multiple rock types.

\subsection{Temporal period designations}

The temporal periods used in this analysis follow guidelines established for the New Mexico Cultural Resource Information System (NMCRIS) in 1993 (Table 1). This is a standard system used by most Cultural Resource Management (CRM) firms throughout New Mexico. Only sites with components belonging to a single temporal period are considered in this study. Sites with multiple recognizable Native American components belonging to more than one temporal period and sites of unknown temporal affiliation are not included. It is understood that there is always potential for multiple components of different temporal periods to contribute to any site assemblage regardless of recognizable components. However, for the purpose of making this study feasible, all artifacts from a site assigned to a given period are considered to belong to that period also.

\subsubsection{Archaic}

The Archaic period spanned from $5500 \mathrm{BC}$ to $200 \mathrm{AD}$. This period is typically defined as being a time during which people were primarily mobile hunters and gatherers that were slowly transitioning to a more sedentary lifestyle. It is distinguished from the earlier Paleoindian period by an increased emphasis on gathering as opposed to a primarily huntingbased subsistence. This is reflected by increased utilization of groundstone tools. The Archaic is generally distinguished from the later Formative period by a lack of ceramics, permanent village structures and intensive agriculture. However, there is often substantial overlap between the periods regarding these characteristics because the transition to sedentism was a very gradual process. Archaic period designations were primarily based on the presence of diagnostic projectile points but were also based on groundstone assemblage analysis and radiocarbon dates obtained from hearths.

\subsubsection{Formative}

The Formative period for southwestern New Mexico is regarded as being occupied by the Mimbres Mogollon tradition between AD 200 and AD 1400. This period is typically characterized by sedentism at the village level and higher, intensive agriculture and the presence of ceramics. This period ends when these sedentary people exit the archaeological record. Around AD 1400 large villages and agricultural plots ceased to be constructed and traditional ceramics were no longer manufactured. This signals the transition to the Protohistoric period.

Formative period designations were primarily based on the presence of diagnostic ceramics but were also based on diagnostic projectile points and radiocarbon dates obtained from hearths.

\subsubsection{Protohistoric}

The NMCRIS guidelines do not provide dates for a distinctive Protohistoric period. For the purposes of this study, it is assigned to cultural groups that existed after the Formative period that had not yet been assimilated into cultural groups with written histories (i.e. Europeans). The maximum extent of this period spanned from AD 1400 to AD 1850 with different groups appearing, disappearing and becoming assimilated at different times. These groups included the Apache, Suma and Manso. People belonging to these groups were typically highly nomadic, built largely impermanent dwellings and used agriculture and ceramics far less than Formative period people. Protohistoric period designations were primarily based on radiocarbon dates obtained from hearths and lithic analysis results but were also based on diagnostic projectile points.

\subsection{Site cluster localities}

The sites used in this study are located over a broad area that is interspersed with lithic source materials (Figs. 1 and 2). Therefore, an analysis of the combined data set by period alone would not be able to roughly model the direction and distance that materials travel from source to destination. Breaking down the assemblage into the individual sites would create data sets that are too small for comparisons and the number of potential comparisons would be unfeasibly large. Instead, sites are divided into clusters that consist of spatially associated sites distinctly separated from one another. This allows for larger data sets while retaining some association with location. These clusters are defined below from south to north.

The Dog Mountains cluster consists of sites located between Eagle Mountain in the West and the eastern foothills of the Dog Mountains in the East. The Little Hat Top Butte cluster consists of four sites located north and northeast of the Alamo Hueco Mountains and south and southeast of the 
Table 1. Period designations, including duration and subsistence patterns for the American Southwest.

\begin{tabular}{lll}
\hline Period & Time Range & Subsistence Pattern \\
\hline Archaic & 5500 B.C. - 200 A.D. & Mobile hunter-gatherer. \\
Formative & 200 A.D. - 1400 A.D. & Sedentism, use of ceramics, locally Mimbres-Mogollon tradition. \\
Protohistoric & 1400 A.D. - 1850 A.D. & Nomadic, less agriculture and sedentism than during Formative Period, not assimilated.
\end{tabular}

Big Hatchet Mountains. The Archaic sites are located near the foot of Little Hat Top Butte on the ridge that joins the Alamo Hueco and Big Hatchet Mountains. The Formative sites are located immediately next to one another approximately $7 \mathrm{~km}$ to the east along an unnamed drainage that leads from Little Hat Top Butte. The Lower Hachita Valley cluster is comprised of sites that are located primarily in the Hachita Valley between the Big Hatchet Mountains and Sierra Rica Mountains. This area is confined to the southeastern part of the valley that is in the United States. The Upper Hatchita Valley site is located in the Hachita Valley approximately $4 \mathrm{~km}$ west of the Sierra Rica Mountains and $6 \mathrm{~km}$ northeast of the northwestern Big Hatchet Mountains. The Doyle Peak cluster includes four sites that are located along a stretch of access road approximately $10 \mathrm{~km}$ long that runs between the Sierra Rica Mountains and the Apache Hills. Doyle Peak is located near the middle of this stretch.

The Three Sites cluster consists of three sites on the international border approximately $3 \mathrm{~km}$ west of the Carrizalillo Hills and $4 \mathrm{~km}$ south of the foothills of the Cedar Mountains and the Nineteen Canyon site located along drainage on the eastern slopes of the Carrizalillo Hills approximately $200 \mathrm{~m}$ north of the international border.

\subsection{Procurement strategy analysis}

In this contribution, we utilize the information gathered from the material descriptions, local geology and geology map to examine potential procurement patterns in different areas of the Boot Heel and during different time periods. Distances to source areas and assemblage proportions are the primary data that are used to conduct this analysis. Arakawa and Nicholson (2010) effectively employed minimum-energy pathways (which take into account the differences in energy expended in traversing varying terrain) in their analysis of lithic procurement patterns and territoriality in the central Mesa Verde region. We opted to use simple straight-line distances in part because this was a preliminary study but mainly because the lithic procurement behaviors of mobile hunter-gatherers are fundamentally different from that of the sedentary agriculturalists.

For the purposes of creating calculable distances for material travel, site clusters are simplified to single points on the maps. These are calculated as the geographic centers of all sites within a cluster belonging to the same temporal pe- riod. The Universal Transverse Mercator (UTM) coordinates for the site datums, obtained with GPS units, were averaged to create a single set of coordinates that represents the geographic center of each cluster. These coordinates were then converted to latitude and longitude and plotted on geologic maps of the region to the nearest minute.

Exact provenances for most of the materials in this study are largely unknown. Therefore, sources for materials were selected with the assumption that the most parsimonious options (i.e. the closest sources) were utilized by inhabitants of the site clusters under study. It is understood that this is highly unrealistic given the nature of human mobility patterns, but it allows for a basis of comparison. Sources for materials are defined as either the geologic units identified during the construction of the map or known source localities identified during survey. The source for each material type in each cluster is then defined as the potential source that has the shortest radial distance to the geographic center of the cluster. Distances were estimated by measuring with calipers to the nearest hundredth of a millimeter on the map and converting to kilometers. A few of the longer distances that could not be accurately estimated on the map were calculated with Google Earth. These distances are represented with arrows on the geologic maps.

Proportions of material types were analyzed statistically among the assemblages using Homogeneity of Proportion tests based on the chi-square probability distribution. Further analysis was conducted on the individual material types using Fisher's Exact Two-Proportion tests with Bonferroni error rates. Significance was determined at $p=0.05$. These analyses were carried out with MINITAB and SPSS statistical software programs. Proportions are represented on the map with shaded arrows indicating material type contributions to the assemblage in $25 \%$ intervals.

The distance and proportion data were also combined to form the Average Minimum Distance (AMD) of transport for all materials to the individual site clusters. This figure is calculated with the following formula:

$i=s$

$\mathrm{AMD}=\sum p_{i} d_{i}$

$i=1$ 
where $\mathrm{p}_{i}$ is the proportion and $\mathrm{d}_{i}$ is the distance in kilometers to nearest potential source for the $i$ th material type in the assemblage containing $s$ types. This provides a figure that accounts for the contribution of each artifact to the distance that materials travelled from source to destination (site cluster). Comparisons of this figure were conducted among time periods both within site clusters and for the entire assemblage.

\section{Material descriptions}

Samples characteristic of each area of the Boot Heel are described in detail below and are divided into appropriate rock type categories.

\subsection{Igneous rocks: extrusive}

\subsubsection{Rhyolite}

Rhyolite specimens in the HV 5-8 area were examined in photographs and include large cobbles commonly found in the centers of roasting pits and some projectile points. Many of the projectile point specimens are pale pink to pinkish gray in color and are porphyritic with large euhedral, transparent quartz crystals and lesser lathe-shaped, transparent crystals tentatively identified as sanidine. Some projectile points from the area were constructed from pyroclastic rhyolites with fragments of other rock types (primarily pumice) included in a fine-grained groundmass.

Samples of rhyolite from the Three Sites area are pale red in color and show less color variation than rhyolites from the other areas. Some of the samples are pyroclastic and included rounded pumice and fragments of what have been tentatively identified as siltstone. Rhyolite samples are porphyritic aphanitic, sometimes faintly foliated, with small phenocrysts of euhedral quartz, sanidine and plagioclase feldspar. Samples of rhyolite recovered from the Nineteen Canyon area are pale red to moderate red in color, with little color variation. Samples are porphyritic aphanitic, sometimes faintly foliated, with small phenocrysts of euhedral quartz, sanidine and plagioclase feldspar. One sample contains plagioclase feldspar and small amphibole needles.

\subsubsection{Andesite}

Andesite specimens examined in photographs from the HV 5-8 area are aphanitic to fine-grained porphyritic. Porphyritic specimens exhibit small, white, opaque feldspar crystals. Because these materials were examined in photographs, it is not possible to determine which type of feldspar is present.

Specimens of andesite from the Three Sites excavations, examined in the laboratory and ranging in color from grayish red to light brownish gray, are porphyritic aphanitic and have a distinctive mottled appearance. Phenocrysts include pyroxene, amphibole (commonly twinned) and quartz. No biotite was identified in hand sample. Pyroxene crystals tend to be weathered out of the host rock, leaving small holes that show two cleavage planes at $90^{\circ}$. One sample of andesite recovered from the area may be pervasively thermally altered as all phenocrysts and the groundmass are the same grayish red color.

Andesite specimens from the Nineteen Canyon excavations are medium gray to pale brown and are porphyritic aphanitic, with mottled appearances. Phenocrysts include pyroxene, feldspar, and rare biotite. No quartz was identified in hand sample. Individual crystals of biotite (and possibly very small magnetite) have red oxidation halos.

\subsubsection{Basalt}

Basalt from the HV 5-8 area was examined in photographs and several projectile points were constructed from aphanitic, nonvesicular basalt that is black in color and of ten weathered to an orange-brown. Manos were constructed from vesicular basalt that is also black in color and weathered to a pale gray. These specimens were all examined in photographs, so the presence or composition of any small phenocrysts could not be positively identified.

Specimens of basalt in the Three Sites area are dark gray and occasionally weathered to a pale yellowish brown. They are aphanitic and locally contain abundant vesicles, some of which are long and thin, lending a "burrowed" appearance to the rock. One sample has rare, very small feldspar lathes, although phenocrysts are usually not visible. Specimens from the Nineteen Canyon area are dark gray, aphanitic and locally contain abundant vesicles that are aligned along flow bands. As with the Three Sites basalt, phenocrysts are not visible.

\subsubsection{Dacite}

In the HV 5-8 area, a dark gray aphanitic dacite with rare sanidine and biotite crystals has been collected from a possible quarry site. The groundmass is generally too fine grained to identify its composition, but has local areas of larger crystals with either biotite or very small pyroxene crystals. While this material does not contain quartz phenocrysts, as would be expected in a dacite or a rhyolite, more mafic minerals (such as pyroxene) are not present in the mineral assemblage, such that this rock should not be termed an andesite, in spite of its darker color.

\subsubsection{Ash-Flow Tuff}

Ash-flow tuff (AFT) specimens from the HV 5-8 area were identified in photographs and are pale gray in color and appear ash rich. Most of the materials used to construct lithic artifacts were semi-welded tuffs that are harder and less obviously ash-rich. 


\subsubsection{Obsidian}

Obsidian objects from the HV 5-8 area were examined in photograph and consist primarily of projectile points that are either opaque black or translucent olive green to black.

A single obsidian fragment was recovered from the Three Sites area that is grayish black in color, opaque with a waxy luster and with radial fracture lines. Fragments of obsidian recovered from the Nineteen Canyon are black and opaque. Near the edges, where the rock is thin enough to be translucent, the material exhibits an olive green tinge, similar to obsidian flakes from the Antelope Wells obsidian field.

\subsection{Sedimentary rocks}

\subsubsection{Sandstone and siltstone}

HV 5-8 sandstone samples are dark brown to purple brown volcaniclastics that are medium to coarse grained, poorly sorted and with angular to subangular grains. Siltstone samples from the Three Sites area are pale red or grayish orange to light brown in color. Samples are too fine grained to identify mineral composition and may have undergone very lowgrade metamorphism. Sedimentary structures identified include relict cross-laminations and planar laminations. Sandstone samples from the Nineteen Canyon area are arkoses that are grayish red to grayish orange in color. These rocks are medium to coarse grained, moderately well sorted and the grains themselves are subangular. They contain up to $80 \%$ feldspar and approximately $20 \%$ quartz with rare lithic grains. Hematite cement coats the grains, giving these rocks a mottled red and pink color. No sedimentary structures were observed in hand-sample. Siltstone samples range in color from moderate red to pale olive. Few of the samples are metamorphosed fully to slate, but show signs of very low temperature heating and/or slightly higher pressures. Most are quartzose with relict cross-laminations or tabular bedding. Some samples are micaceous and others have been metamorphosed to such a degree that they are very silicic and almost chert-like in appearance. One sample has a distinctive red and yellow mottling that probably reflects diagenetic mottling prior to alteration.

\subsection{Metamorphic}

\subsubsection{Quartzite}

Quartzite from the HV 5-8 area are buff to purple in color and range from coarse grained to very fine grained. Some of the very fine-grained quartzites can be mistaken for coarsely crystalline chert without examination under a binocular microscope. Usually relict sedimentary structures and grains can be identified in the quartzites and include laminations, cross-laminations and occasional pebbles of other lithologies.
Specimens of quartzite from the Three Sites area range in color from pale purple to moderate orange. All are fine grained with occasional medium-grained quartz crystals that are transparent. These larger, very clear quartz crystals may indicate higher degrees of metamorphism than samples without these crystals were subjected to. Two samples include pebbles of quartzite of a different texture.

Quartzite samples from the Nineteen Canyon area are pale red to grayish orange and very fine to fine-grained. Several samples include 10 to 15 per cent lithic grains, although all samples are predominantly quartzose. Many display relict cross-laminations and some samples have been metamorphosed enough that grain boundaries have become diffuse and silicic rinds have developed on the outer surfaces. Four samples are arkosic to subarkosic with pyrite crystals or pyrite replaced with botryoidal goethite. The pyrite and goethite are enclosed in red oxidation halos.

\subsection{Chert and chalcedony}

\subsubsection{Chert}

Chert from the HV 5-8 area was examined in photographs and includes a variety of colors and textures, including the distinctive golden-brown color of Eagle Mountain chert, gray, red, white, pink, black and yellow. Textures range from brecciated to massive.

Chert from the Three Sites area are brown, black, red and ivory in color and seams of pale blue or white-blue are common. Textures observed in the chert from this area include lacy, massive, coarsely crystalline, mottled, brecciated, distorted laminated and dendritic. All specimens are opaque with a waxy luster, though some are duller than others. Weathering rinds (cortex) are common as are pores filled with prismatic quartz crystals. Two samples are redorange to red-brown in color with brecciated texture. Chert samples from the Nineteen Canyon area include black, red blue, white, pink and gray varieties. Textures observed in these specimens include lacy, massive, coarsely crystalline, mottled, distorted laminated, banded (faint) and concentrically zoned. Veins of more translucent material are common. Weathering rinds (cortex) are common as are pores filled with prismatic quartz crystals. Two samples are orange mottled chert.

\subsubsection{Chalcedony}

Chalcedony found in the HV5-8 area were examined in photographs, as well as in the field and is a translucent to nearopaque white and bluish brown material with some pink and pale red coloring. The weathered exterior or rind is usually ivory or brown in color.

Chalcedony fragments from the Three Sites excavations are a variety of colors, including yellow, white, pale blue, gray, and pale brown, pink and orange, and are translucent 
with semi-waxy to dull luster. Textures identified include concentrically zoned mottles $(2-3 \mathrm{~cm}$ in diameter), streaking and massive. Some specimens still have a weathering rind (cortex) present that is nodular. Chalcedony fragments from the Nineteen Canyon excavations are light gray, pale orange, light yellow and bluish gray, and are massive, with few variations in texture. Cortex is common on most specimens, as is the occurrence of small clusters of prismatic quartz crystals.

\section{Local geology}

\subsection{HV 5-8}

In the eastern Boot Heel, geologic source areas include the Alamo Hueco and Dog Mountains, the Big and Little Hatchet Mountains, the Sierra Rica and Apache Hills, outcrops in northern Mexico and possibly minor sources in the southern and eastern Animas Mountains. The southern and eastern Animas Mountains are dominated by rhyolitic units that are Eocene to Oligocene in age and these flows are related to both eruptive suites found throughout the Boot Heel (35.2-32.7 Ma, 27.6-26.8 Ma; McIntosh and Bryan, 2000). The OK-Bar Conglomerate, which covers large areas of the southern Animas Mountains, is comprised of boulders and cobbles of locally derived volcanic materials and includes significant amounts of obsidian weathering from the Park Tuff (Zeller, 1962; Shackley, 1995). The Alamo Hueco and Dog Mountains are comprised of mostly Tertiary volcanics, including rhyolites, tuffs and andesitic basalts (Zeller, 1959; Wilks, 2005). Chalcedony is a common hydrothermally deposited mineral phase in areas with silicic igneous rocks (e.g. White and Corwin, 1961). In some places, local faults are excellent sources of hydrothermally deposited chalcedony: LA 162029 is a local procurement area for chalcedony that is near a faulted outcrop. There are local outcrops of Cretaceous limestone and sandstone to the northwest of and in the northern Alamo Huecos that describe the hinge of a syncline plunging to the southeast. U-Bar Ridge, the area for the type section of the U-Bar Formation, forms the hinge of the syncline. Sites LA 161106 and LA 161996, Eagle Mountain Chert procurement sites, lie on small remnants of this syncline.

The Big Hatchet Mountains are primarily Paleozoic limestone of Pennsylvanian and Permian age, with smaller outcrops of the Cambrian-Ordovician Bliss Sandstone and Mississippian to Devonian carbonates along the margins of the range (Zeller, 1965). Paleozoic limestone is a potential source area for chert of a variety of colors (white, gray, lavender, red, brown and black). Specifically, the Permian Concha Limestone is the only unit that has been documented that produces red and lavender chert nodules (Zeller, 1965). Other colors of chert cannot be specifically linked to any Paleozoic limestone unit. The Bliss Sandstone contains arkosic sandstones, conglomerates that contain some Precambrian quartzite boulders, a white orthoquartzite and a sequence of thick sandy dolomite (Zeller, 1965).

The Little Hatchet Mountains are comprised of fault blocks of a variety of lithologies. The southern Little Hatchet Mountains include outcrops of Precambrian and Tertiary granite, upper Cretaceous to lower Tertiary diorite and monzonite intrusions, Pennsylvanian carbonates, Lower Cretaceous limestone and sandstone of the U-Bar and Mojado Formations and Upper Cretaceous basalt (Ringbone Formation) (Zeller, 1970). The central Little Hatchets are primarily Cretaceous sedimentary rocks, including the Lower Cretaceous Hell-to-Finish, Mojado, U-Bar Formations and Upper Cretaceous Ringbone Formation (Zeller, 1970). This region of the Little Hatchets also includes minor lower Oligocene rhyolite and AFTs and Cretaceous to Tertiary volcaniclastic units. The northern part of the Little Hatchets is a lower Oligocene rhyolite and AFT complex with minor outcrops of Ringbone Formation basalt and andesite (Zeller, 1970).

The Sierra Rica are primarily composed of the Lower Cretaceous Mojado Formation, metamorphosed to quartzite, with minor Paleozoic limestone and Cretaceous-Tertiary latite (Zeller, 1965). A local peak, Doyle Peak, has been identified as a source of chert. The Apache Hills are also comprised of Mojado Formation quartzite and upper Cretaceous to lower Tertiary latite, and include lower Oligocene to upper Eocene andesitic flows (Zeller, 1965). These andesitic flows are the likely source of the secondary deposits of chalcedony at the procurement site LA 161989. The Sierra Rica and Apache Hills are the most likely source area of the distinctive pale purple to gold quartzite identified in site clusters in the Nineteen Canyon, Hachita Valley and Doyle Peak area. To the southeast of the the Sierra Rica and Apache Hills, in northern Mexico, is a large outcrop of Paleozoic limestone. This outcrop is a potential source area for a variety of chert types for both the northern HV 5-8 area and for the Nineteen Canyon-Three Sites area (see below).

Lithic source materials in the southern HV 5-8 area include rhyolite and tuff, basalt, obsidian, quartzite, chert and chalcedony. The central HV 5-8 area includes chert sources (from limestone), as well as quartzite. The northern HV 58 area includes rhyolite, diorite, granite, basalt, sandstone, quartzite, chert and chalcedony as possible lithic source materials.

\subsection{Three sites and Nineteen Canyon}

The Three Sites and Nineteen Canyon excavation area is situated in the southwestern Carrizalillo Hills, southeast of the Cedar Mountains. Potential lithic procurement source areas for these two sites include the Carrizalillo Hills, the Apache Hills (and possibly Sierra Rica), Paleozoic outcrops in northern Mexico, the Cedar Mountains, the Tres Hermanas and the northern Burro Mountains. In addition, obsidian is probably being procured from the Sierra Fresnal secondary field in northernmost Mexico. The Carrizalillo Hills are a Lower 
Oligocene rhyolite and AFT complex (Wilks, 2005). The Apache Hills and Sierra Rica are a source for quartzite and Paleozoic outcrops in northern Mexico may be a procurement area for a variety of cherts. The Cedar Mountains include upper Oligocene to lower Miocene basalts and basaltic andesites, Miocene to Pliocene basalts to andesites, upper Oligocene rhyolites and lower Oligocene silicic domes, flows and rhyolite AFTs. Sedimentary strata present in the Cedar Mountains include minor outcrops of Lower Cretaceous strata (Wilks, 2005). The Klondike Hills are probably not an immediately useful procurement source but they do contain relatively well-preserved sequences of Paleozoic limestone, dolostone and shale that may have served as a chert source (Armstrong, 1970).

The Tres Hermanas are a Tertiary monzonite and Upper Eocene to Lower Oligocene andesite complex with minor outcrops of Pennsylvanian and Permian strata (Seager and Clemons, 1988; McLemore, 2000a; Wilks, 2005). Granite identified in the Nineteen Canyon excavations is most likely to have come from the Tres Hermanas monzonite outcrops (as opposed to the granite present in the southernmost Little Hatchets). The northern Burro Mountains, north of Lordsburg, contain outcrops of the Beartooth Quartzite, which contains very small cubes of pyrite (McLemore, 2000b). There is a possibility that quartzites from the Lower Cretaceous Mojado Formation may contain pyrite, though the occurrence of pyrite in these quartzites has not been documented. Disseminated pyrite has been found in the Tres Hermanas in fissure veins, though it has not been reported as being found in a quartzite (McLemore, 2000a).

\section{Procurement site descriptions}

\subsection{Northern Dog Mountains procurement sites}

\subsubsection{Northern Dog Mountains local geology}

The geology of the northern Dog Mountains, and southern Alamo Hueco Mountains, is dominated by silicic igneous units, including porphyritic and pyroclastic rhyolite, tuff, andesite and dacite with some basalt (Zeller, 1959; Wilks, 2005). There are minor outcrops of Lower Cretaceous sedimentary strata, that include the U-Bar and Mojado Formations, as well as younger fan deposits that include cobbles and pebbles of local bedrock. The rhyolite in the Dog Mountains is Eocene to Oligocene in age and is part of the older eruptive suite found in the Boot Heel (35.2-32.7 Ma; McIntosh and Bryan, 2000). Rhyolite from these flows ranges in color from light gray to pale red and usually includes phenocrysts of quartz and sanidine. Some rhyolite is pyroclastic and has moderately large pumice fragments that are flattened and elongated (termed fiamme for their shape), which show flow foliation. Tuff that was used to make lithic artifacts is usually welded and buff to dark gray in color. Andesite is

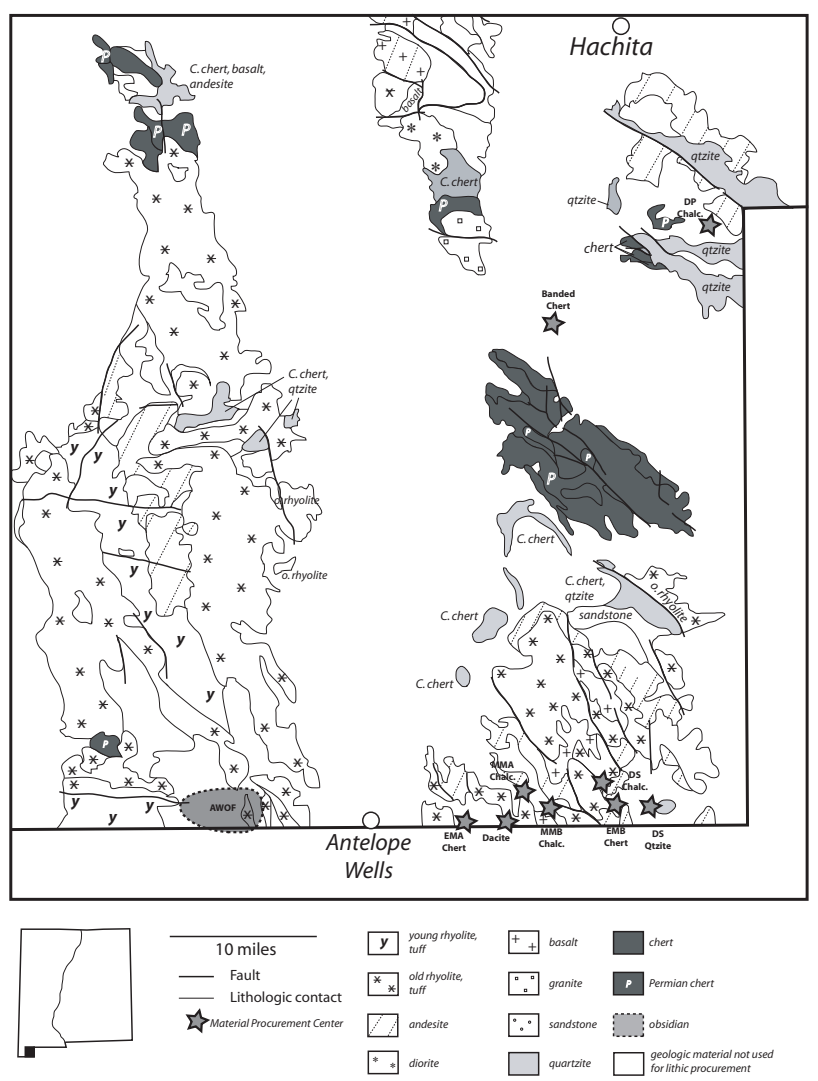

Fig. 3. Locations of lithic procurement sites ("quarries") in the southwestern New Mexico with detailed lithologies.

dark green or has a black and green speckled appearance and contains very small phenocrysts of feldspar. Dacite from the northern Dog Mountains is pale gray in color and is generally aphanitic, though some fragments contain rare phenocrysts of sanidine and biotite, which has been altered to a bronze color. Basalt is either vesicular or nonvesicular and generally aphanitic, though some fragments contain feldspar lathes. Chert from the U-Bar Formation can be a variety of colors and textures, though this unit contain a distinctive orange-brown, mottled or brecciated chert, termed the Eagle Mountain Chert. Chalcedony is translucent to semi-opaque and ranges in color from ivory to pale red, pale blue or black. Quartzite, present in the Lower Cretaceous Mojado Formation, weathers to a dark brown, and can be tan or lavender in fresh sample.

\subsubsection{Dog Mountains procurement site descriptions: Eagle Mountain A chert (LA 161106)}

The Eagle Mountain A chert procurement site is located along a very small outcrop of the Lower Cretaceous UBar Formation that had not previously been mapped (e.g., Zeller, 1959; Fig. 3). The chert, a distinctive orange-brown in color with red flecks and massive, brecciated or mottled 
textures, occurs as nodules and laterally discontinuous irregularly shaped beds within a limestone that is a laminated to hummocky laminated gray wackestone to packstone. The laminations often exhibit soft-sediment deformation and fossils have been replaced chert. In field samples and photographs, none of the fossil material could be positively identified. We interpret the Eagle Mountain A limestone outcrop to be Lower Cretaceous U-Bar Formation because the outcrop lies on the trace of the southwestern limb of a southeastward plunging syncline described by mapped outcrops of U-Bar Formation to the north and east (U-Bar Ridge describes the hinge of this syncline). This outcrop is a primary source for Eagle Mountain chert.

\subsubsection{Dog Mountains procurement site descriptions: Eagle Mountain Dacite (LA 161105)}

The Eagle Mountain dacite procurement site occurs on a low rise immediately north of the international border (Fig. 3). Low, narrow ridges of dacite trend northwestsoutheast across the rise and hundreds of artifacts have been observed in the immediate vicinity. The dacite is aphanitic and pale gray with rare phenocrysts of sanidine and biotite. The site occurs along the western edge of a band of rhyolite outcrop and is a localized occurrence of dacite that is a primary procurement source. Dacite is not common in the Boot Heel and this procurement locality is the only are where this material was worked extensively.

\subsubsection{Dog Mountains procurement site descriptions: Middle Mountain A chalcedony (LA 161108)}

The Middle Mountain A chalcedony procurement site, in the western part of the pass between the Dog Mountains and the Alamo Hueco Mountains, is located in a broad valley on a low hill of exposed welded tuff/rhyolite bedrock (Fig. 3). The chalcedony is ivory, pale blue or pale red in color, is often laminated to nodular in texture and occurs in very dense concentrations on the surface of the site. The Middle Mountain A site is a secondary deposit of chalcedony that probably originated in fractures within the andesite and rhyolite outcrops immediately to the north and has weathered out onto the modern land surface.

\subsubsection{Dog Mountains procurement site descriptions: Middle Mountain B chalcedony (LA 162029)}

The Middle Mountain B procurement site is in the eastern part of the pass between the Dog Mountains and Alamo Hueco (Fig. 3). The site is on a south-facing slope where the toes of two hills meet. These hills are two different igneous units with the contact between the two occurring in the saddle between the two hills. The Middle Mountain B chalcedony is probably weathering out of the contact zone or fractures within either igneous unit and is a primary chalcedony source. The Middle Mountain B chalcedony is pale blue or pale brown in color with primarily massive or nodular textures. The chalcedony found loose on the surface of the site occurs as much larger blocks and nodules than at Middle Mountain A.

\subsubsection{Dog Mountains procurement site descriptions: Dog Springs chalcedony (LA 89049)}

The Dog Springs chalcedony site is located on the eastern flank of the pass between the northern Dog Mountains and the Alamo Hueco Mountains (Fig. 3). It occurs in a small valley between two ridge lines of rhyolite and is on or near two contacts between flow units and is immediately north of a thrust fault. The surface of the site is primarily rhyolite outcrop and the chalcedony is probably weathering out of the contacts between flow units or from fractures within the units that may be related to the fault to the south and is therefore a primary source. Chalcedony from this procurement locality is similar in colors and textures to that of other chalcedony procurement sites.

\subsubsection{Dog Mountains procurement site descriptions: Eagle Mountain B chert (LA 161996)}

The Eagle Mountain B procurement site contains chert nodules similar in color and texture to the Eagle Mountain A chert. The Eagle Mountain B chert is golden-brown to reddish brown. Golden-brown pieces tend to have lacey to massive textures, whereas red specimens have lacey to brecciated textures. Blue translucent chalcedony is present as discrete blebs or disseminated through the red varieties. The range of textures seen in the Eagle Mountain B chert is not as diverse and there seems to be a stronger association between color and texture type than is observed in the Eagle Mountain A chert. The Eagle Mountain B chert occurs as nodules littering the land surface on a north-facing slope near Dog Springs Ranch (Fig. 3). There are no documented outcrops of limestone near the site, indicating that the chert nodules are a secondary deposit. Tertiary fanglomerates containing Paleozoic limestone to the east are down-slope of the site, and are unlikely to be the source for the Eagle Mountain B chert. A plausible explanation is that the chert nodules represent erosional remanents of a local outcrop of U-Bar Formation that has since been eroded away, leaving only the chert nodules.

\subsubsection{Dog Mountains procurement site descriptions: Dog Springs quartzite (LA 85792)}

The Dog Springs quartzite procurement area is located on the alluvial plain between the Dog Mountains to the west and Haystack Mountain to the east (Fig. 3). The site occurs on the north side of a low rise formed by a weathered outcrop of bedrock that is a primary source for the artifacts at this site. This site was originally described by Human System Resources in 1991 and they identified the bedrock as 
quartzite. Site survey undertaken in the summer of 2007 reclassified the site as resting on basalt bedrock. However, geologic maps of the area describe the hills immediately east of the site as Lower Cretaceous Mojado Formation and do not document basalt near this site (Zeller, 1959; Wilks, 2005). Therefore, it is unlikely that the bedrock here is basalt, but is most likely the "brown-weathered sandstone" or quartzite observed by Zeller (1959).

\subsection{Hachita Valley and Doyle Peak procurement sites}

\subsubsection{Hachita Valley and Doyle Peak local geology}

The Hachita Valley is bounded by the Big Hatchet Mountains to the southwest, the Little Hatchet Mountains to the west and the Sierra Rica and Apache Hills to the northeast and east. Doyle Peak is located in the valley between the Sierra Rica to the south and the Apache Hills to the north-northeast. The Big Hatchet Mountains are composed primarily of $\mathrm{Pa}$ leozoic limestone units with extensive outcrops of the Cambrian Bliss Formation at the northern end of the range (Zeller, 1966). The Little Hatchet Mountains contain a variety of lithologies that range from Precambrian and Tertiary granite at the southern end of the mountains to Paleozoic and Cretaceous sedimentary strata and Cenozoic igneous outcrops in the central and northern mountains (Zeller, 1970). The Sierra Rica are composed of the Lower Cretaceous Mojado Formation that has been so silicified that the sandstone units are now quartzite (Zeller, 1966). Minor fault blocks of Paleozoic limestone occur on the western end of the Sierra Rica. The Apache Hills are a mixture of silicified Mojado Formation and extensive andesite flows. Doyle Peak is a fault block of Paleozoic limestone (Wilks, 2005).

\subsubsection{Hachita Valley and Doyle Peak procurement site descriptions: Hachita Valley banded chert (LA 161991)}

The Hachita Valley banded chert procurement site is not close to prominent outcrops of chert-bearing rock, and so is tentatively identified as a procurement site on the basis of the high density of raw banded chert nodules found (Fig. 3). The site is on a southwest-northeast trending gravelly terrace that overlooks the Hachita Valley to the southeast. The Big Hatchet Mountains are about two miles to southwest. Chert utilized at this site is a distinctive lavender and reddish pink banded material that is most likely to have come from the Permian Concha Limestone. The Concha Limestone is exposed in the center and southwestern flank of the Big Hatchet Mountains. The Hachita Valley procurement site is a secondary deposit of this material after the chert was eroded out of outctops in the Big Hatchet Mountains and redeposited as terrace gravels within the Hachita drainage.

\subsubsection{Hachita Valley and Doyle Peak procurement site descriptions: Doyle Peak chalcedony (LA 161989)}

The Doyle Peak chalcedony procurement site is on a westfacing slope west of a low ridge that overlooks an incised arroyo to the south. Doyle Peak is approximately two to three miles to the west-southwest (Fig. 3). The chalcedony occurs as two to ten centimeter diameter nodules on the modern land surface and is a secondary deposit. The original source of the chalcedony is probably from flow contacts or within-unit fracture zones in the andesite in the southern Apache Hills.

\section{Analysis results}

The results below are visually represented in the maps (Figs. 4-7) and Tables 2 and 3 below. The statistics give us and the reader a sense of the strength of similarity and difference at a given significance level but, given the limitations of the data set and the preliminary nature of the study, we also tried to identify patterns that might be culturally if not statistically significant that can be tested by future research. Once again, site clusters are presented from south to north.

\subsection{Dog Mountains}

This cluster consists of Archaic and Formative sites. Each set of sites has a distinct location separate from one another. The Archaic sites are located on the eastern flanks of the Dog Mountains and the Formative sites are west of the Dog Mountains centered an area south of Middle Mountain.

Exactly $50 \%$ of the Archaic assemblage is made up of Eagle Mountain chert and chalcedony (Figs. 4, 5). The nearest Eagle Mountain chert source is approximately $1 \mathrm{~km}$ away at LA 161996. The site cluster lies on a chalcedony producing fault zone and one of the sites in the cluster, LA 89049, is a chalcedony procurement site. Rhyolite and tuff are also immediately available. Basalt is available in the southern Alamo Hueco Mountains, also very nearby. Other cherts are available in the southern Dog Mountains in northern Chihuahua. The most distant source is for obsidian, at the Antelope Wells field.

The Formative assemblage is dominated by chalcedony (Figs. 4, 6). This chalcedony is abundant in this region, outcropping at both LA 161108 and LA 162029, which is located exactly at the geographic center for the Formative sites. Rhyolite and tuff are also immediately available. Basalt, once again, arrived from the southern Alamo Hueco Mountains. Eagle Mountain chert came from LA 161996 and other cherts are again available in the southern Dog Mountains. The nearest quartzite is a small Cretaceous outcrop east of the Dog Mountains. Permian chert is coming from the southern end of the Big Hatchet Mountains and the obsidian is coming from the Antelope Wells obsidian field $22 \mathrm{~km}$ to the west. 


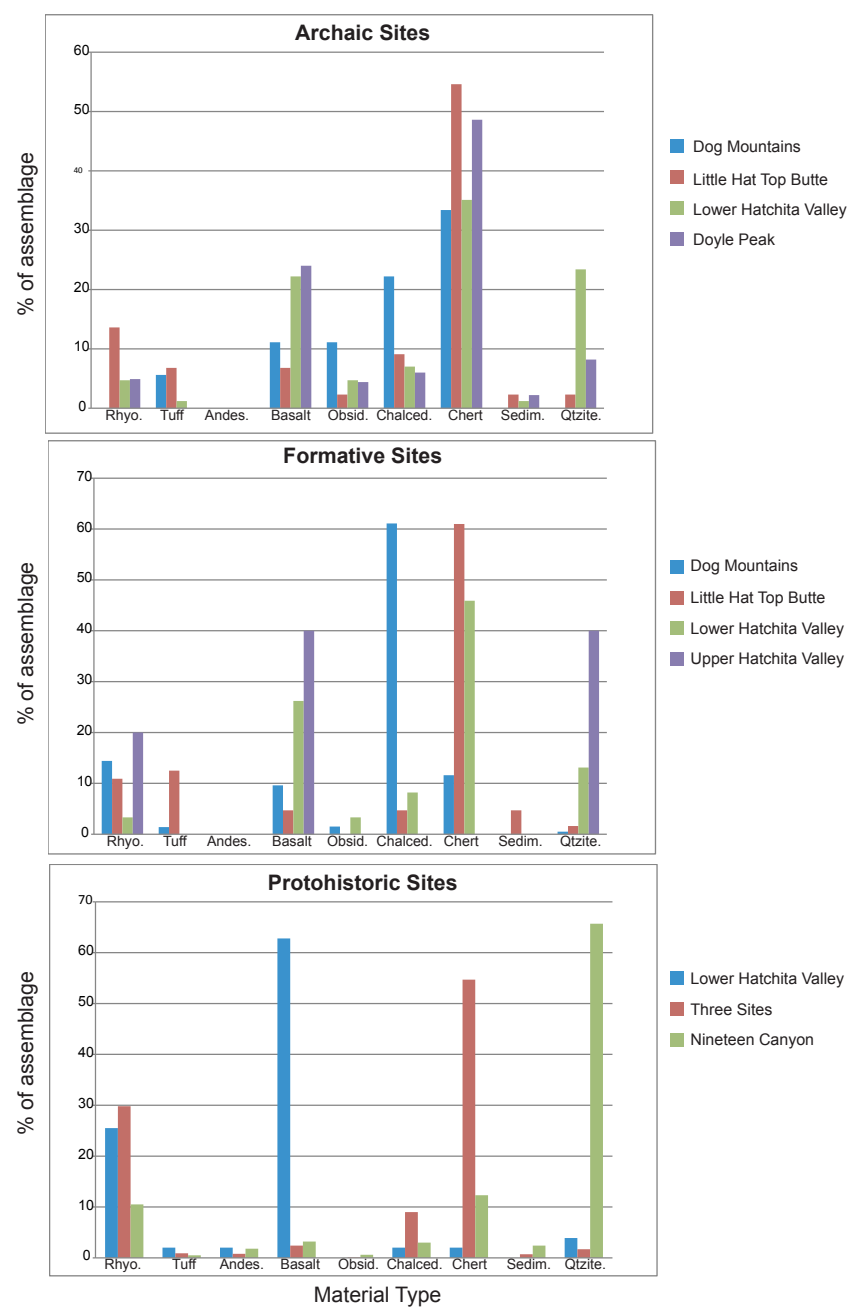

Fig. 4. Histograms by Period designation showing materials used in each site cluster. Some materials with low counts (i.e., prismatic quartz) were omitted from the histogram. Rhyo. = rhyolite, Andes. = andesite, Obsid. = obsidian, Chalced. = chalcedony, Sedim. $=$ sedimentary rock, Qtzite $=$ quartzite.

The Homogeneity of Proportions test between the two assemblages was highly significant $(p<0.000)$. The Fisher's Tests indicate that the Archaic assemblage has a significantly higher proportion of Eagle Mountain chert (24\% more of the assemblage) and and that the Formative assemblage has a significantly higher proportion of chalcedony (39\% more of the assemblage). These differences appear to be a direct result of the locations of the site clusters. The Archaic sites are located very near an Eagle Mountain chert source and the Formative sites are sitting on an expansive chalcedony outcrop. Another interesting difference that is not statistically significant is the higher proportion of obsidian in the Archaic assemblage.
The AMDs for the Archaic and Formative assemblages are 4.00 and $1.73 \mathrm{~km}$, respectively. These are the lowest values in this study. This is because these clusters are immediately near sources of materials that were most utilized in their assemblages. In fact, the only reason the Archaic AMD is more than twice as large as that of the Formative is the higher proportion of obsidian from the Antelope Wells obsidian field.

\subsection{Little Hat Top Butte}

Similar to the Dog Mountains site cluster, the Archaic and Formative sites for the Little Hat Top Butte cluster group separately in distinct areas. The Archaic sites are grouped around the base of Little Hat Top Butte and the Formative sites are grouped farther to the east, about approximately one mile west of the international border.

The majority of artifacts in the Archaic assemblage are Eagle Mountain chert, other cherts and rhyolite (Figs. 4, 5). The nearest known Eagle Mountain chert source is LA 161996, however these sites are located very near a large outcrop of U-Bar Formation, which could potentially yield other sources of Eagle Mountain chert. Quartzite is also immediately available in the U-Bar Formation. Other cherts, including Permian cherts, arrived from nearby in the southern Big Hatchet Mountains. Rhyolite, tuff and chalcedony came from less than a kilometer away in volcanic flows north of the Alamo Hueco Mountains. Sandstone could be procured immediately to the south in the Emory Canyon area. Basalt is available in the northern and central Alamo Hueco Mountains. By far, the farthest potential source is the Antelope Wells obsidian field $33 \mathrm{~km}$ to the southwest.

The Formative assemblage is very similar to the Archaic assemblage in terms of material proportions (Figs. 4, 6). Furthermore, the nearest sources of materials are identical. The exception is the presence of limestone in the Formative assemblage, the nearest known source of which is the same as for chert, in the southern Big Hatchet Mountains. In general, the sites are slightly further from the sources than the Archaic sites.

The Homogeneity of Proportions test between the two assemblages was not significant $(p=0.644)$. Fisher's tests were also run to confirm this result and they too showed no significant differences. The proportions among the assemblages are very similar. The only noticeable anomaly is the presence of one piece of obsidian in the Archaic assemblage which had to be procured from a relatively long distance.

The AMDs for the Archaic and Formative assemblages are 7.43 and $9.37 \mathrm{~km}$, respectively. These are relatively low and, like the Dog Mountains figures, are the result of being fairly close to multiple procurement areas. The slight difference of these values is, again, the result of the Formative sites being slightly farther from the source areas. 
Table 2. Count and percentage of assemblage of geologic materials documented in the eastern Boot Heel region. Upper number in cell is the count, lower number is the percentage of the assemblage. $\mathrm{A}=$ Archaic, $\mathrm{F}=$ Formative, $\mathrm{P}=$ Protohistoric.

\begin{tabular}{|c|c|c|c|c|c|c|c|c|c|c|c|}
\hline & \multicolumn{2}{|c|}{ Dog Mountains } & \multicolumn{2}{|c|}{$\begin{array}{l}\text { Little Hat Top } \\
\text { Butte }\end{array}$} & \multicolumn{3}{|c|}{ Lower Hatchita Valley } & $\begin{array}{l}\text { Upper } \\
\text { Hatchita } \\
\text { Valley }\end{array}$ & $\begin{array}{l}\text { Doyle } \\
\text { Peak }\end{array}$ & $\begin{array}{l}\text { Three } \\
\text { Sites }\end{array}$ & $\begin{array}{l}\text { Nineteen } \\
\text { Canyon }\end{array}$ \\
\hline Material & A & $\mathrm{F}$ & A & $\mathrm{F}$ & A & $\mathrm{F}$ & $\mathrm{P}$ & $\mathrm{F}$ & $\mathrm{A}$ & $\mathrm{P}$ & $\mathrm{P}$ \\
\hline Rhyolite & $\begin{array}{l}3 \\
16.7\end{array}$ & $\begin{array}{l}30 \\
14.4\end{array}$ & $\begin{array}{l}6 \\
13.6\end{array}$ & $\begin{array}{l}7 \\
10.9\end{array}$ & $\begin{array}{l}8 \\
4.7\end{array}$ & $\begin{array}{l}2 \\
3.3\end{array}$ & $\begin{array}{l}13 \\
25.5\end{array}$ & $\begin{array}{l}1 \\
20.0\end{array}$ & $\begin{array}{l}9 \\
4.9\end{array}$ & $\begin{array}{l}228 \\
29.8\end{array}$ & $\begin{array}{l}107 \\
10.5\end{array}$ \\
\hline Tuff & $\begin{array}{l}1 \\
5.6\end{array}$ & $\begin{array}{l}3 \\
1.4\end{array}$ & $\begin{array}{l}3 \\
6.8\end{array}$ & $\begin{array}{l}8 \\
12.5\end{array}$ & $\begin{array}{l}2 \\
1.2\end{array}$ & - & $\begin{array}{l}1 \\
2.0\end{array}$ & - & - & $\begin{array}{l}7 \\
0.9\end{array}$ & $\begin{array}{l}5 \\
0.5\end{array}$ \\
\hline Andesite & - & - & - & - & - & - & $\begin{array}{l}1 \\
2.0\end{array}$ & - & - & $\begin{array}{l}6 \\
0.8\end{array}$ & $\begin{array}{l}18 \\
1.8\end{array}$ \\
\hline Basalt & $\begin{array}{l}2 \\
11.1\end{array}$ & $\begin{array}{l}20 \\
9.6\end{array}$ & $\begin{array}{l}3 \\
6.8\end{array}$ & $\begin{array}{l}3 \\
4.7\end{array}$ & $\begin{array}{l}38 \\
22.2\end{array}$ & $\begin{array}{l}16 \\
26.2\end{array}$ & $\begin{array}{l}32 \\
62.8\end{array}$ & $\begin{array}{l}2 \\
40.0\end{array}$ & $\begin{array}{l}44 \\
24.0\end{array}$ & $\begin{array}{l}18 \\
2.4\end{array}$ & $\begin{array}{l}33 \\
3.2\end{array}$ \\
\hline Diorite & - & - & - & - & - & - & - & - & $\begin{array}{l}2 \\
1.1\end{array}$ & - & - \\
\hline Granite & - & - & - & - & $\begin{array}{l}1 \\
0.6\end{array}$ & - & - & - & - & - & $\begin{array}{l}1 \\
0.1\end{array}$ \\
\hline Obsidian & $\begin{array}{l}2 \\
11.1\end{array}$ & $\begin{array}{l}2 \\
1.0\end{array}$ & $\begin{array}{l}1 \\
2.3\end{array}$ & - & $\begin{array}{l}8 \\
4.7\end{array}$ & $\begin{array}{l}2 \\
3.3\end{array}$ & - & - & $\begin{array}{l}6 \\
3.3\end{array}$ & $\begin{array}{l}1 \\
0.1\end{array}$ & - \\
\hline $\begin{array}{l}\text { Antelope } \\
\text { Wells } \\
\text { Obsidian }\end{array}$ & - & $\begin{array}{l}1 \\
0.5\end{array}$ & - & - & - & - & - & - & $\begin{array}{l}2 \\
1.1\end{array}$ & - & $\begin{array}{l}3 \\
0.3\end{array}$ \\
\hline $\begin{array}{l}\text { Sierra } \\
\text { Fresnal } \\
\text { Obsidian }\end{array}$ & - & - & - & - & - & - & - & - & - & - & $\begin{array}{l}3 \\
0.3\end{array}$ \\
\hline $\begin{array}{l}\text { Prismatic } \\
\text { quartz }\end{array}$ & - & - & - & - & - & - & - & - & $\begin{array}{l}1 \\
0.6\end{array}$ & - & - \\
\hline Chalcedony & $\begin{array}{l}4 \\
22.2\end{array}$ & $\begin{array}{l}127 \\
61.1\end{array}$ & $\begin{array}{l}4 \\
9.1\end{array}$ & $\begin{array}{l}3 \\
4.7\end{array}$ & $\begin{array}{l}12 \\
7.0\end{array}$ & $\begin{array}{l}5 \\
8.2\end{array}$ & $\begin{array}{l}1 \\
2.0\end{array}$ & - & $\begin{array}{l}11 \\
6.0\end{array}$ & $\begin{array}{l}69 \\
9.0\end{array}$ & $\begin{array}{l}31 \\
3.0\end{array}$ \\
\hline Chert & $\begin{array}{l}1 \\
5.6\end{array}$ & $\begin{array}{l}13 \\
6.3\end{array}$ & $\begin{array}{l}8 \\
18.2\end{array}$ & $\begin{array}{l}13 \\
20.3\end{array}$ & $\begin{array}{l}33 \\
19.3\end{array}$ & $\begin{array}{l}21 \\
34.4\end{array}$ & $\begin{array}{l}1 \\
2.0\end{array}$ & - & $\begin{array}{l}39 \\
21.3\end{array}$ & $\begin{array}{l}298 \\
38.9\end{array}$ & $\begin{array}{l}101 \\
9.9\end{array}$ \\
\hline $\begin{array}{l}\text { Eagle Mtn. } \\
\text { Chert }\end{array}$ & $\begin{array}{l}5 \\
27.8\end{array}$ & $\begin{array}{l}8 \\
3.9\end{array}$ & $\begin{array}{l}13 \\
29.6\end{array}$ & $\begin{array}{l}20 \\
31.3\end{array}$ & $\begin{array}{l}8 \\
4.7\end{array}$ & $\begin{array}{l}4 \\
6.6\end{array}$ & - & - & $\begin{array}{l}7 \\
3.8\end{array}$ & $\begin{array}{l}35 \\
4.6\end{array}$ & $\begin{array}{l}12 \\
1.2\end{array}$ \\
\hline $\begin{array}{l}\text { Permian } \\
\text { Chert }\end{array}$ & - & $\begin{array}{l}3 \\
1.4\end{array}$ & $\begin{array}{l}3 \\
6.8\end{array}$ & $\begin{array}{l}6 \\
9.4\end{array}$ & $\begin{array}{l}19 \\
11.1\end{array}$ & $\begin{array}{l}3 \\
4.9\end{array}$ & - & - & $\begin{array}{l}43 \\
23.5\end{array}$ & $\begin{array}{l}86 \\
11.2\end{array}$ & $\begin{array}{l}12 \\
1.2\end{array}$ \\
\hline Gypsum & - & - & $\begin{array}{l}1 \\
2.3\end{array}$ & - & - & - & - & - & - & - & - \\
\hline Limestone & - & - & - & $\begin{array}{l}3 \\
4.7\end{array}$ & $\begin{array}{l}1 \\
0.6\end{array}$ & - & - & - & $\begin{array}{l}3 \\
1.6\end{array}$ & - & - \\
\hline Sandstone & - & - & $\begin{array}{l}1 \\
2.3\end{array}$ & - & $\begin{array}{l}1 \\
0.6\end{array}$ & - & - & - & $\begin{array}{l}1 \\
0.6\end{array}$ & - & $\begin{array}{l}5 \\
0.5\end{array}$ \\
\hline Siltstone & - & - & - & - & - & - & - & - & - & $\begin{array}{l}5 \\
0.7\end{array}$ & $\begin{array}{l}19 \\
1.9\end{array}$ \\
\hline Quartzite & - & $\begin{array}{l}1 \\
0.5\end{array}$ & $\begin{array}{l}1 \\
2.3\end{array}$ & $\begin{array}{l}1 \\
1.6\end{array}$ & $\begin{array}{l}40 \\
23.4\end{array}$ & $\begin{array}{l}8 \\
13.1\end{array}$ & $\begin{array}{l}2 \\
3.9\end{array}$ & $\begin{array}{l}2 \\
40.0\end{array}$ & $\begin{array}{l}15 \\
8.2\end{array}$ & $\begin{array}{l}13 \\
1.7\end{array}$ & $\begin{array}{l}662 \\
65.0\end{array}$ \\
\hline $\begin{array}{l}\text { Beartooth } \\
\text { Quartzite }\end{array}$ & - & - & - & - & - & - & - & - & - & - & $\begin{array}{l}7 \\
0.7\end{array}$ \\
\hline $\begin{array}{l}\text { Total } \\
\text { Count }\end{array}$ & 18 & 208 & 44 & 64 & 171 & 61 & 51 & 5 & 183 & 766 & 1019 \\
\hline
\end{tabular}




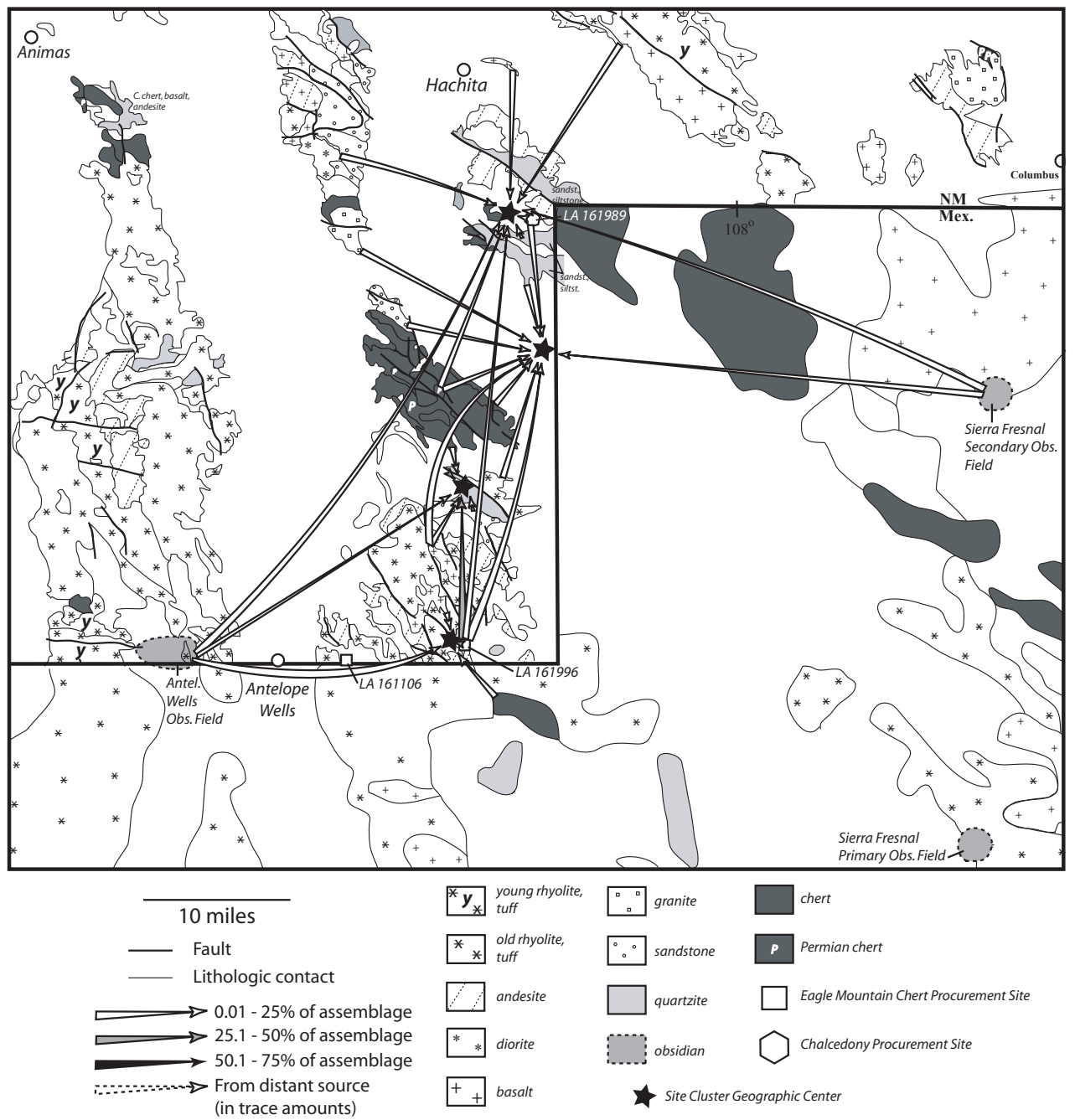

Fig. 5. Geologic map of the Boot Heel of southwestern New Mexico with locations of site clusters and minimum distance movement of geologic materials for sites identified as Archaic.

\subsection{Lower Hachita Valley}

This cluster contains sites from the Archaic, Formative and Protohistoric periods. Nearly all of the sites are located in a tight group near the center of the Hachita Valley basin. As a result, the geographic centers of the Archaic and Protohistoric sites are very close to one another near the international border. There is, however, one Formative site located closer to the foot of the Big Hatchet Mountains. This site draws the geographic center of the Formative sites a few miles to the west.

The Archaic assemblage is comprised mostly of quartzite, basalt and chert (Figs. 4, 5). Quartzite is available in the southern Sierra Rica Mountains, basalt in the northern Alamo Hueco, and chert (and limestone) in the Big Hatchet Mountains. Permian chert is once again available in the central Big Hatchets. The nearest chalcedony source is LA 161989 in the Doyle Peak region. Rhyolite and tuff are available in the volcanic flows north of the Alamo Hueco Mountains. The single piece of sandstone likely came from the Bliss member of the northern Big Hatchet Mountains. The nearest source for the single piece of granite is in the southernmost Little Hatchet Mountains. The nearest known source of Eagle Mountain chert is at LA 161996 . Obsidian is likely coming from the Sierra Fresnal secondary obsidian field in northern Chihuahua.

The Formative assemblage is primarily comprised of chert and basalt (Figs. 4, 6). The sources of materials are identical to those of the Archaic assemblage with one exception: the nearest obsidian source for the Formative is the Antelope Wells obsidian field. In general, it appears that the geographic center of the Formative sites is slightly closer to the source areas than that of the Archaic sites. 


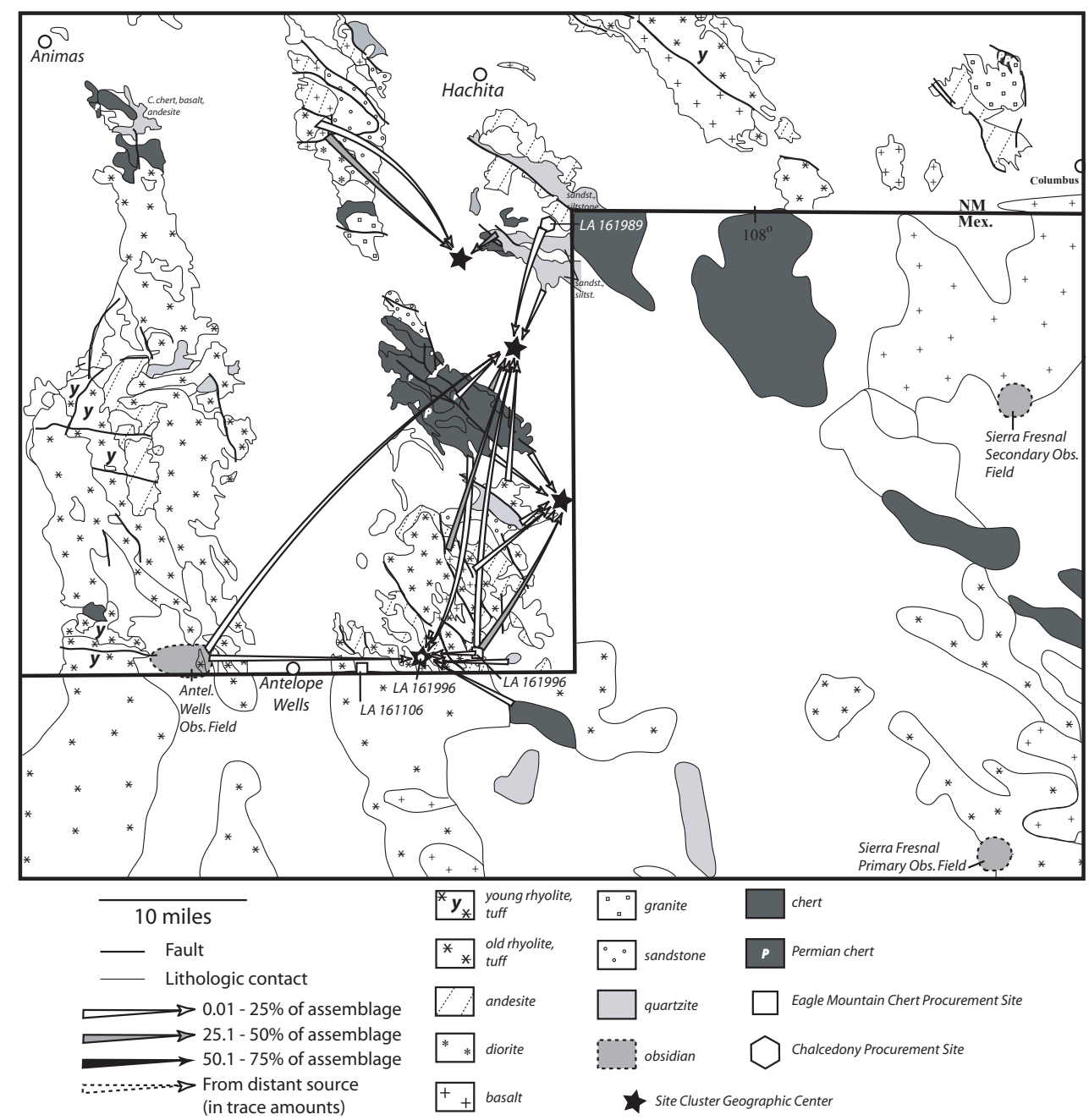

Fig. 6. Geologic map of the Boot Heel of southwestern New Mexico with locations of site clusters and minimum distance movement of geologic materials for sites identified as Formative.

The single site that makes up Protohistoric portion of this cluster is dominated by basalt (Figs. 4, 7). The nearest source area in the Alamo Huecos is fairly distant at approximately $24 \mathrm{~km}$. It could very well be that there is a much nearer source of basalt that has not been identified. This is further elaborated on in the discussion section below. Rhyolite also makes up substantial proportion of the assemblage. The sources for this and the remaining materials are the same as those for the other periods. The only exception is a single piece of andesite that likely comes from the southern Apache Hills.

The Homogeneity of Proportions test between the two assemblages was highly significant $(p<0.000)$. The Fisher's tests clearly indicate that the Protohistoric assemblage is the primary source of differences among the assemblages. It has significantly higher proportions of basalt and rhyolite than both the Archaic and Formative assemblages, a significantly lower proportion of chert than the Formative, and a significantly lower proportion of quartzite than the Archaic. No- table differences that are not significant are that the Formative has a fairly high proportion of chert and the Archaic has fairly high proportions of quartzite and Permian chert.

The AMDs for the Archaic, Formative and Protohistoric assemblages are $15.25,13.82$ and $20.12 \mathrm{~km}$, respectively. The Archaic and Formative figures are only slightly above average, but the Protohistoric figure is the highest among all the clusters. The largest contributor to all of these figures is basalt because of its distant source and substantial contribution to all the assemblages. In the case of the Protohistoric assemblage, basalt accounts for more than three-quarters of the exceptionally high AMD value. If there is a nearer basalt source, these AMDs would be much lower. Rhyolite provides most of the remainder of the Protohistoric figure because of its large contribution to that assemblage. The slight difference between the Formative and Archaic AMDs appears to be the slightly closer proximity of the Formative geographic center to the sources and the higher proportions of quartzite and Permian chert in the Archaic assemblage. 


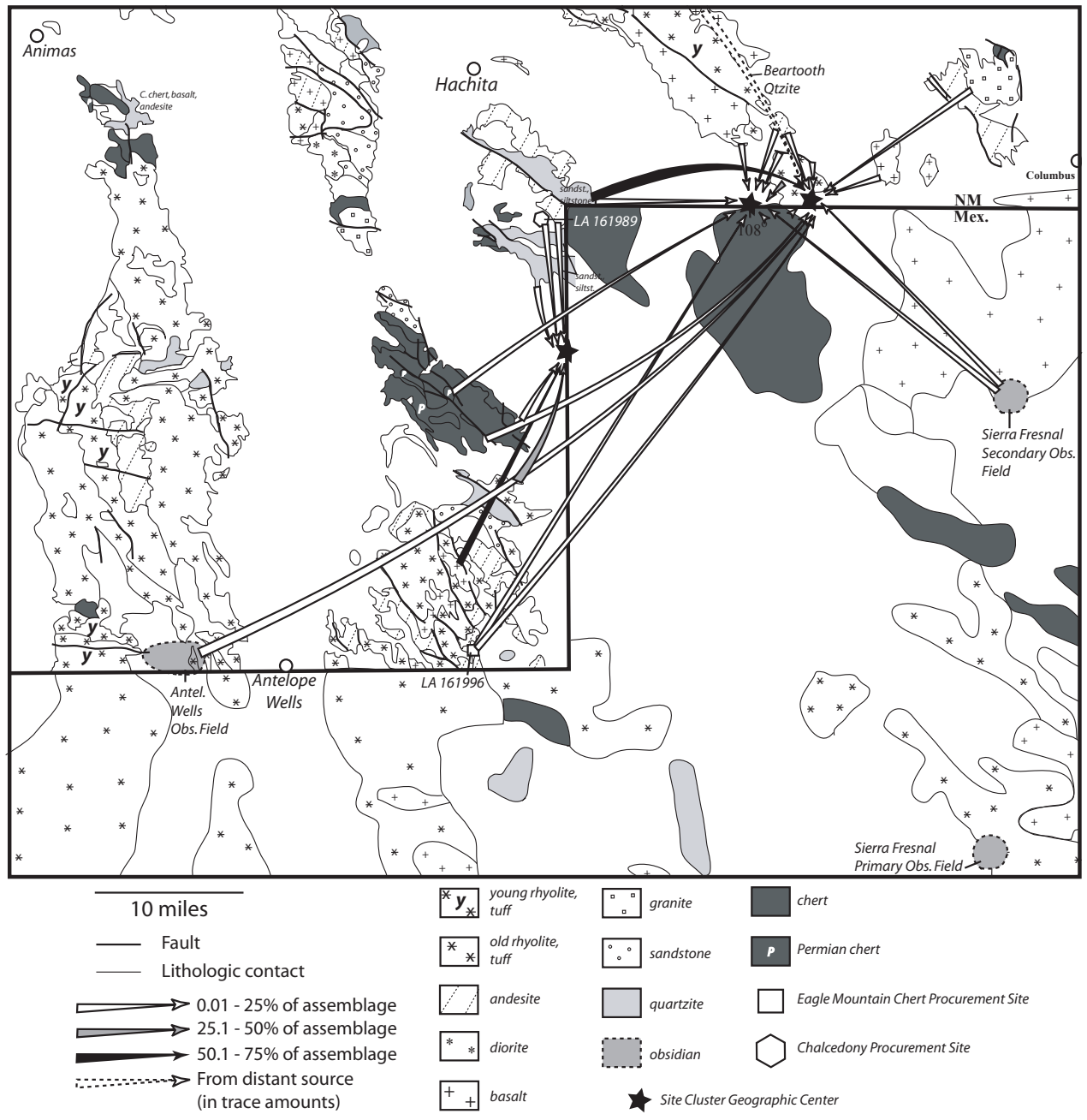

Fig. 7. Geologic map of the Boot Heel of southwestern New Mexico with locations of site clusters and minimum distance movement of geologic materials for sites identified as Protohistoric.

\subsection{Upper Hachita Valley and Doyle Peak}

The Formative site in the upper Hachita Valley lies approximately $7 \mathrm{~km}$ southwest of the geographic center of the Doyle Peak Archaic sites. These sites comprise a single analytical cluster and are only presented with different names to better describe their locations. This need arose because of the large geographic expanse that the Archaic sites are spread across.

The Archaic assemblage is mostly made up of equal parts basalt, Permian chert and other cherts (Figs. 4, 5). The nearest source of basalt is at Flat Hill immediately east of the town of Hachita. Permian chert once again is coming from the central Big Hatchet Mountains. Other cherts and limestone are immediately available around the base of Doyle Peak. Quartzite and sandstone are very close in the Mojado Formation of the Sierra Rica Mountains. The nearest known chalcedony source is LA 161989, which is located within the Archaic site cluster area. Diorite is available in the central Little Hatchet Mountains and the closest rhyolite is found in the Cedar Mountains. More distant is LA 161996, the nearest known source of Eagle Mountain chert. The Sierra Fresnal secondary field is the nearest source of obsidian, but Antelope Wells obsidian was also identified in the assemblage.

The Formative assemblage at LA 161080 was limited to five lithics (Figs. 4, 6). The two pieces of quartzite likely came from the Mojado Formation of the Sierra Rica Mountains, the same as for the Archaic. The two pieces of basalt and single piece of rhyolite, however, were likely procured from the central Little Hatchets. All statistical tests on proportions were not significant. The Formative assemblage is simply too small to derive any inferences about it.

The AMDs for the assemblages are very similar at $13.87 \mathrm{~km}$ for the Archaic assemblage and $13.01 \mathrm{~km}$ for the Formative. These values are average among all values for the clusters. Basalt and, for the Archaic assemblage, Permian chert were the largest contributors to these values because of their high proportions in the assemblages and the long distances to sources. 
Table 3. AMD values by locality cluster.

\begin{tabular}{ll}
\hline Site Cluster ID & $\begin{array}{l}\text { AMD value } \\
(\mathrm{km})\end{array}$ \\
\hline Dog Mountains & \\
Archaic & 4.00 \\
Formative & 1.73 \\
Little Hat Top Butte & \\
Archaic & 7.43 \\
Formative & 9.37 \\
Lower Hatchita Valley & \\
Archaic & 15.25 \\
Formative & 13.82 \\
Protohistoric & 20.12 \\
Upper Hatchita Valley, Doyle Peak & \\
Archaic & 13.87 \\
Formative & 13.01 \\
Three Sites, Nineteen Canyon & \\
Protohistoric - Three Sites & 8.91 \\
Protohistoric - Nineteen Canyon & 18.10 \\
\hline
\end{tabular}

\subsection{Three Sites and Nineteen Canyon}

The Three Sites and Nineteen Canyon assemblages are both Protohistoric and located about $6 \mathrm{~km}$ from each other. Radiocarbon dates were obtained from both clusters indicating that Nineteen Canyon, which is the eastern cluster, is slightly older with a proposed occupation range between AD 1420 and 1540. Three Sites, to the west, is suggested to date from AD 1620 to 1800 . These assemblages are compared to explore any potential differences between these periods/culture groups.

The Three Sites assemblage is primarily made up of chert and rhyolite (Figs. 4, 7). Chert is immediately available from a Paleozoic outcrop that extends southward into Chihuahua. Rhyolite and tuff are available just to the east in the Carrizalillo Hills, though there is a possibility that rhyolite was being procured immediately, at LA 85779 . Andesite, basalt and chalcedony were procured a little further away from the southern Cedar Mountains and northern Carrizalillo Hills. The nearest siltstone and quartzite outcrops are in the Mojado Formation of the northern Sierra Rica Mountains. The single piece of obsidian was likely to have come from the Sierra Fresnal secondary field. The only known source of Permian chert is in the Big Hatchets. The furthest source is for Eagle Mountain chert at LA 161996.

Nineteen Canyon is dominated by a distinctive grey-topurple fine-grained quartzite from the northern Sierra Ricas. Many of the other sources are identical to that of the Three Sites assemblage. The exceptions are basalt from domes east of the Carrizalillo Hills, a piece of granite from the Tres
Hermanas, Antelope Wells obsidian and Beartooth quartzite from the Burro Mountains southwest of Silver City.

The Homogeneity of Proportions test between the two assemblages was highly significant $(p<0.000)$. The Fisher's tests indicated that the Nineteen Canyon assemblage has a significantly higher proportion of quartzite and the Three Sites assemblage has significantly higher proportions of rhyolite, chalcedony, chert, Eagle Mountain chert and Permian chert. Clearly the large abundance of quartzite in the Nineteen Canyon assemblage is the largest source of difference between the assemblages. Quartzite makes up $63 \%$ more of its assemblage than it does in Three Sites.

The AMDs for Three Sites and Nineteen Canyon are 8.91 and $18.10 \mathrm{~km}$, respectively. The Three Sites figure is relatively low and the Nineteen Canyon figure is one of the highest. The largest proportions of materials for Three Sites could have been procured locally, while the quartzite at Nineteen Canyon had to have been carried at least $22 \mathrm{~km}$.

\subsection{Entire assemblage}

A final analysis was conducted among the Archaic, Formative and Protohistoric assemblages of the entire data set. The overall mean AMDs for the three periods were compared using a standard one-way ANOVA. There were no significant differences $(p=0.403)$, possibly because of the small number of values. The means for the Archaic and Formative samples are similar at 10.65 and $10.53 \mathrm{~km}$, respectively, while that of the Protohistoric is higher at $15.72 \mathrm{~km}$. That higher value is probably a function of the physical separation of the Protohistoric components at Three Sites and Nineteen Canyon from the Archaic and Formative components in the main project area, however. The results therefore suggest that lithic procurement behaviors and the scale of mobility were similar during all three temporal periods.

\section{Summary and discussion}

The preceding analysis is a first attempt at quantifying the lithic procurement behavior of Native American populations in the Boot Heel area of southwestern New Mexico. As such, it was directed toward three basic questions: (a) what is the distribution of lithic raw materials in the area, (b) are there definable patterns of lithic procurement during different temporal periods, and (c) are there substantial differences in lithic procurement patterns among the different temporal periods?

As might be expected in a preliminary study, the data used have some unavoidable inadequacies. Ideally, individual sites rather than geographical clusters would have been the units of analysis and the precise locations of all lithic sources would have been identified. The artifact samples from individual sites were too small for meaningful statistical analyses, however, and our ability to identify source 
locations was limited by the scale of the available geological maps. The latter was particularly a problem when identifying source locations in Mexico. In addition, mapping was restricted mainly to primary sources, although it is clear that prehistoric groups did collect some lithic raw materials from gravel beds and other secondary sources. Unfortunately, information on secondary source locations was not available.

A third potential problem is the dating of site components, which was based primarily on the presence of temporally diagnostic projectile points and ceramics. These artifacts are avidly collected by some local residents, and their selective removal could mask the presence of one or more temporal components. Protohistoric groups in the region are also known to have scavenged and reused earlier projectile points and occasionally prehistoric pottery (Seymour, 2010); consequently, the discard of scavenged materials could result in the erroneous identification of Archaic and/or Formative components at Protohistoric sites. Because multi-component sites were dropped from the analysis, the latter behavior may have resulted in the exclusion of some Protohistoric sites, while the potential effects of recent collecting may have led to the inadvertent inclusion of sites that are actually mixed assemblages from two or more periods.

Despite the limitations of the data, analysis of material type proportions within assemblages and distances to nearest sources revealed some intriguing patterns. Most notably, one of our expectations going into the project was that Archaic and Protohistoric populations in the region were more mobile than Formative populations, and that those differences would be reflected in lithic procurement patterns. The analysis results did not match those expectations, however, which forced us to re-examine our assumptions about the relationship of lithic procurement to mobility.

As summarized by Arakawa and Nicholson (2010), ethnographic studies suggest that the daily activities of sedentary agriculturalists tend to be concentrated in a primary area within $1-2 \mathrm{~km}$ of the residence that encompasses principal water sources and most agricultural fields. A secondary exploitation area then extends outward to 5-10 $\mathrm{km}$ from the residence where most of the hunting and fuel wood collection is done, and beyond it is a non-exploitive zone where other materials including lithic and clay sources may be located. Given this evidence that agricultural groups tend to reduce their mobility and the cost of travelling to procure resources, Arakawa and Nicholson argue that Formative groups generally exploited the closest sources of suitable lithic material and followed a least-energy pathway in transporting lithic raw materials from the quarry location to the settlement. Their model assumes direct procurement - that task groups travelled to the source areas specifically to collect lithic raw materials and to transport those materials back to the residence for later use.

Although the average minimum distance (AMD) values for the Formative components in our study appear consistent with this model, nearly all of the sites are gathering camps rather than permanent habitations. Most of these sites are dated by ceramics to the Classic Mimbres phase (AD 1000$1150)$ or possibly earlier. Settlement patterns in the Boot Heel area during this period are poorly defined (Nelson and Anyon, 1996), but the Dog Mountain and Doyle Peak clusters each have one site that might be a small Mimbres phase residence, and there is a previously documented Mimbres phase village in close proximity to the Lower Hachita cluster. It is therefore possible that the camps are clustered within the outer zones surrounding those or other nearby settlements. Alternatively, the camps could be associated with groups that are seasonally mobile and less dependent on agriculture than is generally postulated for the Mimbres Mogollon. In either case, the evidence indicates that the bulk of lithic materials at the camps were obtained from nearby sources.

In contrast to farming, the hunting and gathering adaptations of Archaic and Protohistoric groups in southern New Mexico tend to be characterized by high residential mobility, with groups shifting locations as food resources within a $10-15 \mathrm{~km}$ foraging radius of the camp are depleted (Bettinger, 1991; Kelly, 1995). With this level of mobility, it is doubtful that those groups would have made special trips to procure lithic raw materials. More probably, lithic procurement was "embedded" in subsistence activities (Binford, 1979). That is, when there was a perceived need, lithic raw materials were collected as encountered during the search for food resources. This strategy is more efficient than direct procurement since the energy expended is only marginally higher than the cost of collecting only subsistence resources.

The AMD values do not reflect a high level of mobility, however. The overall AMD values for the Archaic components are about the same as that for the Formative components and, although the value for the Protohistoric components is somewhat higher, the difference is not statistically significant. This suggests either that there was a relatively low level of mobility during all three temporal periods or that there is an unanticipated disconnect between the overall mobility and lithic procurement behavior of the groups.

The idea that lithic raw materials can tell us something about the movements of prehistoric hunter-gatherers is based on two assumptions. First, it is assumed that mobile groups carried a small supply of lithic materials in the forms of tools, cores, and/or flake blanks that were intermittently discarded at different locations as stone tools were used, refurbished, and replaced. Second, because there are practical limits on the total amount of gear that a group traveling on foot can carry (Parry and Kelly, 1987), it is further assumed that the groups would have periodically replenished their supply from different sources as the group moved through their annual range. From these assumptions, it follows that the lithic materials discarded at a site should evidence the prior movements of the site's occupants over at least a portion of their annual range. The AMD values, which summarize the distances that lithic materials were transported from their source locations, should therefore provide both a direct indicator of 
lithic procurement behavior and an indirect measure of relative mobility.

In mapping the potential source locations, however, it was evident that moderate to good quality tool stone was ubiquitous in the areas surveyed. Under these conditions, there would have been little need for mobile groups to transport lithic raw materials because suitable tool stone could be readily obtained wherever the groups established their camps. Thus the energy expended in transportation could be minimized by carrying only enough lithic material to meet the group's immediate tool requirements (Parry and Kelly, 1987; Andrefsky, 1994). This alternative model suggests that the relatively low AMD values for Archaic and Protohistoric components in the individual clusters accurately reflect the lithic procurement behavior of those groups but, because little lithic material appears to have been transported from one location to another, the overall AMD values for the different temporal periods are probably a poor indicator of relative mobility in this instance.

The proportions of the lithic materials provide some evidence for mobility and the general direction of prior movements, however. For the Archaic components, the relatively high proportion of obsidian in the Dog Mountain cluster suggests that groups were moving eastward from the Antelope Wells source area (Findlow and Bolognese (1980) also noted that the contribution of Antelope Wells obsidian decreases with distance to the east and north of the procurement field). In addition, the proportions of Eagle Mountain chert are relatively high in both the Dog Mountain and Little Hat Top Butte clusters, possibly indicating that subsequent movements were to the north.

For the Protohistoric components, the distinctive gray-topurple quartzite identified in the Nineteen Canyon assemblage was observed by one of the authors (KZ) at an outcrop in the Mojado Formation of the Sierra Rica Mountains $22 \mathrm{~km}$ to the west, suggesting an eastward movement vector. Similarly, the Protohistoric assemblage from the Lower Hachita Valley cluster is dominated by basalt and rhyolite, the nearest sources of which are to the south and west. Interestingly, no directionality was observed in the Formative components, which suggests that the geographical clusters for this period might represent discrete resource areas that were exploited by different sedentary groups.

This article presents some preliminary observations concerning lithic procurement patterns in a relatively poorly understood region of the American Southwest based on a joint archaeological and geological study. The analysis was undertaken to trace the movements of Archaic, Formative, and Protohistoric populations in the region based on the varieties of tool stone recorded at the sites recorded during archaeological survey. It began by mapping known and potential sources of lithic raw materials in the region and relating the tool stone found in different locations to those sources. The proportions of different lithic materials and distances to their respective sources were then summarized using an average minimum distance (AMD) statistic and these data were evaluated using previously developed energy-optimization models of lithic procurement behavior for sedentary and mobile groups. The results of this analysis suggest that resident groups during all three temporal periods were collecting tool stone from the closest suitable sources and were transporting only minimal amounts of lithic material from one location to another. We argue that this predominant pattern of local procurement reflects the most energy-efficient behavior in an area where tool stone is abundant and ubiquitous, and does not necessarily indicate a uniform subsistence strategy or low level of mobility.

Multi-disciplinary research to understand past human adaptations is most profitably conducted at the regional level where patterns of human-environment interactions are most apparent. As illustrated here, lithic source studies have proven a valuable tool for moving from site-centered to regional analysis both because stone tools and manufacturing debris are typically the most common artifacts at a site and because the distribution of lithic raw material sources, unlike some other environmental variables, has not changed over span of human occupation. The analysis can be completed at little cost during the early stages of research and, despite the inevitable limitations of the available data, generally reveals behaviorally-meaningful patterns that can be used to guide subsequent work. Given these advantages, it is our hope is that more archaeologists and geologists will adopt this approach in the future.

Acknowledgements. We thank F. Arakawa and an anonymous reviewer for their helpful comments on the manuscript. We also thank the United States Department of Homeland Security for allowing publication of this research and U.S. Customs and Border Protection for their assistance during geological surveying.

Edited by: C. De La Rocha

\section{References}

Andrefsky, W.: Raw material availability and the organization of lithic technology, Am. Antiquity, 59, 21-34, 1994.

Arakawa, F. and Nicholson, C.: Prehistoric resource procurement in the central Mesa Verde region: A study of human mobility and social interaction using GIS, Int. J. Humanities and Arts Computing, 3, 85-100, 2010.

Armstrong, A., Silberman, M., Todd, V., Hoggatt, W., and Carten, R.: Geology of the central Peloncillo Mountains, Hidalgo County, New Mexico, New Mexico Bureau of Mines and Mineral Resources Circular, 158, 19 p., 1978.

Binford, L. R.: Organization and formation processes: Looking at curated technologies, J. Anthropol. Res., 35, 255-273, 1979.

Bettinger, R. L.: Hunter-Gatherers: Archaeological and Evolutionary Theory, Plenum Press, 1991.

Findlow, F. and Bolognese, M.: An initial examination of prehistoric obsidian exchange in Hidalgo County New Mexico, Kiva, 45, 227-251, 1980. 
Kelly, R. L.: The Foraging Spectrum: Diversity in Hunter-Gatherer Lifeways, Smithsonian Institution Press., 1995.

McIntosh, W. and Bryan, C.: Chronology and geochemistry of the Boot Heel volcanic field, New Mexico, New Mexico Geological Society Guidebook, 51, 157-174, 2000.

McLemore, V.: The Tres Hermanas mining district, Luna County, New Mexico: New Mexico Geological Society Guidebook, 51, 40-41, 2000a.

McLemore, V.: Geology and mineral resources of the Wild Horse Mesa area, Burro Mountains, Grant County, New Mexico, New Mexico Geological Society Guidebook, 51, 254-252, $2000 \mathrm{~b}$.

Nelson, B. A. and Anyon, R.: Fallow Valleys: Asynchronous Occupations in Southwestern New Mexico, Kiva, 61(3), 275-294, 1996.

Parry, W. J. and Kelly, R. L.: Expedient Core Technology and Sedentism, in: The Organization of Core Technology, edited by: Johnson, J. and Morrow, C. A., 285-307, Westview Press, 1987.

Reynolds, S.: Geologic Map of Arizona (1:1,000,000 scale), in: The Geologic Evolution of Arizona, edited by: Jenney, J. and Reynolds, S., 866 p., 1988.

Seager, W. and Clemons, R.: Geology of the Hermanas quadrangle, Luna County, New Mexico, New Mexico Bureau of Mines and Mineral Resources GM 63: 1:24,000 scale, 1 sheet, 1988.

Seymour, D.: Contextual Incongruities, Statistical Outliers, and Anomalies: Targeting Inconspicuous Occupational Events, American Antiquity, 75(1), 158-176, 2010.

Shackley, M. S.: Sources of archaeological obsidian in the greater American Southwest: An update and quantitative analysis, American Antiquity 60, 531-551, 1995.
Shackley, M. S.: Source provenance of obsidian artifacts from Prehistoric sites in the Bootheel region, Hidalgo County, southwest New Mexico, Berkeley Archaeological Lab report, 7 p., 2009.

Soule, J.: Structural geology of the northern part of the Animas Mountains, Hidalgo County, New Mexico, New Mexico State Bureau of Mines and Mineral Resources Circular, 125, 15 p., 1972.

White, J. F. and Corwin, J. F.: Synthesis and origin of chalcedony, The American Mineralogist, 46, 112-119, 1961.

Wilks, M. (compiler): New Mexico Geologic Highway Map. New Mexico Bureau of Geology and Mineral Resources Map 1:1,000,000 scale, 2005.

Zeller, R.: Reconnaissance geologic map of Dog Mountains quadrangle. New Mexico Bureau of Mines and Mineral Resources Geologic Map 8 1:62,500 scale, 1959.

Zeller, R.: Reconnaissance geologic map of southern Animas Mountains. New Mexico Bureau of Miners and Mineral Resources Geologic Map 17: 1:62,500 scale, 1962.

Zeller, R.: Stratigraphy of the Big Hatchet Mountains area, New Mexico, New Mexico Bureau of Mines and Mineral Resources Memoir 16:128, 1966.

Zeller, R.: Geology of the Little Hatchet Mountains, Grant and Hidalgo Counties, New Mexico Bureau of Mines and Mineral Resources Bulletin 96:22, 1970. 